$\ll$ Research Note»

\title{
Intracerebroventricularly Administration of Glucagon-Like Peptide-1 Induces Sleep-Like Behavior in the Neonatal Chick
}

\author{
Takashi Bungo ${ }^{a}$, Shin-ichi Kawakami ${ }^{\mathrm{b}}$, Atsushi OHgushi ${ }^{\mathrm{a}}$, \\ Masataka Shimojo ${ }^{a}$, Yasuhisa Masuda ${ }^{a}$, Noboru SAITO $^{c}$, Kunio Sugahara ${ }^{d}$, \\ Shin Hasegawa ${ }^{\mathrm{e}}$ and Mitsuhiro Furuse ${ }^{\mathrm{a}}$ \\ ${ }^{a}$ Laboratory of Feed Science, Department of Animal Science, Division of Animal and Marine \\ Bioresources Science, Graduate School of Bioresource and Bioenvironmental Science, \\ Kyushu University, Fukuoka 812-8581, Japan \\ b Department of Animal Production, Kyushu National Agricultural Experiment Station, \\ Kumamoto 861-1192, Japan \\ ${ }^{c}$ Graduate School of Bioagricultural Science, Nagoya University, Nagoya 464-8601, Japan \\ ${ }^{\mathrm{d}}$ Department of Animal Science, Faculty of Agriculture, \\ Utsunomiya University, Utsunomiya 321-8505, Japan \\ ${ }^{\mathrm{e}}$ Laboratory of Biological Function and Metabolism, Division of Bioscience, Graduate School of \\ Science and Technology, Kobe University, Kobe-shi 657-8501, Japan
}

\begin{abstract}
It is known that central administration of glucagon-like peptide-1 (GLP-1) (7-36) amide suppresses feeding in rats and chicks, but the mechanisms for this response are still open with special reference to the chick. The present study was done to determine whether GLP-1 induces sleep-like behavior on the neonatal chick. Intracerebroventricular injection of GLP-1 (7-36) amide altered, in a dose-dependent fashion, the behavioral postures of chicks and induced sleep-like behavior compared with the saline control. These results indicate that GLP-1 in the central nervous system may be one of the factors to induce sleeping of the neonatal chick.
\end{abstract}

(Jpn. Poult. Sci., $36: 377-381,1999)$

Key words : glucagon-like peptide-1 (GLP-1), sleep-like behavior, intracerebroventricular injection, neonatal chick

\section{Introduction}

Glucagon-like peptide-1 (GLP-1) is recognized as an inhibitor of food intake in rats (TURTON et al., 1996 ; NAVARRo et al., 1996 ; TANG-CHRISTENSEN et al., 1996) and chickens (FURUSE et al., $1997 \mathrm{a}, \mathrm{b}$ ), but the mechanisms for this anorexigenic effect of GLP-1 are poorly defined. One of the systems suggested by LARSEN et al. (1997) for the central GLP -1 depression of food intake in the rats is by GLP-1 activation of the hypothalamo-

Received June 14, 1999 Accepted July 26, 1999

* Correspondence should be addressed to: Dr. M. Furuse, Laboratory of Feed Science, Department of Animal Science, Division of Animal and Marine Bioresources Science, Graduate School of Bioresource and Bioenvironmental Science, Kyushu University, Fukuoka 812-8581, Japan

Tel. \& Fax (81) (92) 642-2953

E-mail : furuse@agr.kyushu-u.ac.jp 
pituitary-adrenocortical axis. This is primarily stimulation of corticotropin releasing factor neurons, and this activation may be responsible for the inhibition of feeding behavior. In fact, plasma corticosterone concentration was rapidly increased after central administration of GLP-1 (7-36) amide in the rat (WANG et al., 1996). On the contrary, central GLP-1 (7-36) amide did not alter plasma corticosterone level in the neonatal chick (Furuse et al., $1997 \mathrm{c}$ ). Central nervous system of GLP-1 action in avian species has not been clarified.

Although there was no systematic attempt to quantify behavior, FuRuse et al. (1997 c) found that the chicks were very calm and moved less after intracerebroventricular (i.c.v.) injection of GLP-1. This finding hypothesized that sleep-like behavior induced by GLP-1 (7-36) amide may contribute to the anorexigenic effect of GLP-1 in the neonatal chick. Thus, it is important to quantify the narcoleptic response, which was caused by GLP-1 for the clarification of central nervous system of GLP-1 action.

To confirm the relationships between GLP-1 and sleep-like behavior, therefore, the categorized posture of neonatal chicks was observed after central administration of chicken GLP-1 (7-36) amide.

\section{Materials and Methods}

Day-old male Single Comb White Leghorn chicks (Julia; Murata Hatchery, Fukuoka, Japan) were housed in a windowless room at a constant temperature of $28^{\circ} \mathrm{C}$. Lighting was provided continuously. The birds were given free access to a commercial starter diet (Toyohashi Feed and Mills Co. Ltd., Aichi, Japan) and water. They were distributed into experimental groups based on their body weight, so that the average body weight was as uniform as possible for each treatment. After being distributed into each group, birds (3-day-old, 10 birds per group) were observed the postures at 30 min immediately after injection, because anorexigenic effect of GLP-1 (7-36) amide $(0.03 \mu \mathrm{g})$ became fainter after $60 \mathrm{~min}$ following administration (FURUSE et al., $1997 \mathrm{~b}$ ). As referring to VAN LUIJTELAAR et al. (1987), four behavioral categories were distinguished : (1) active wakefulness ; (2) standing/sitting with eyes open ; (3) standing motionless with eyes closed ; (4) sitting motionless with head drooped (sleeping posture). Observation was performed by a trained observer who was not informed of each treatment.

The birds were i.c.v. injected with the solutions $(10 \mu l)$ using a microsyringe according to the method of DAvis et al. (1979). Chicken GLP-1 (7-36) amide was purchased from Peptide Institute, Inc. (Osaka, Japan) and was dissolved in a $0.1 \%$ Evans Blue solution, which was prepared in $0.85 \%$ saline. GLP-1 (7-36) amide was administered at the dose levels of $0,0.01,0.03$ and $0.1 \mu \mathrm{g}$. At the end of the experiment, the birds were sacrificed by decapitation, followed by brain sectioning to identify the location of injected drug. Data from the individuals that were not verified to have Evans Blue dye present in the lateral ventricle were deleted. The number of birds used was as follows : $9(0 \mu \mathrm{g}) ; 9(0.01 \mu \mathrm{g}) ; 8(0.03 \mu \mathrm{g})$ and $8(0.1 \mu \mathrm{g})$.

Data were subjected to t-test for ordered classifications (SNEdECor and Cochran, 1967) between control and each dose of GLP-1 (7-36). 
Table 1. Influence of GLP-1 (7-36) amide on the various behavioral categories of the neonatal chick after 30 min following administration

\begin{tabular}{|c|c|c|c|c|c|c|}
\hline \multirow{2}{*}{\multicolumn{2}{|c|}{ Treatment (n) }} & \multicolumn{4}{|c|}{$\begin{array}{l}\text { Number of chicks } \\
\text { with the postures of score }\end{array}$} & \multirow{2}{*}{$\begin{array}{l}\text { Pvs the control } \\
\text { for posture } \\
\text { score }\end{array}$} \\
\hline & & 1 & 2 & 3 & 4 & \\
\hline Control & (9) & 4 & 3 & 0 & 2 & - \\
\hline $0.01 \mu \mathrm{g}$ & (9) & 0 & 4 & 2 & 3 & $\mathrm{P}<0.2$ \\
\hline $0.03 \mu \mathrm{g}$ & (9) & 0 & 3 & 1 & 4 & $\mathrm{P}<0.1$ \\
\hline $0.1 \mu \mathrm{g}$ & (9) & 0 & 2 & 0 & 6 & $\mathrm{P}<0.025$ \\
\hline
\end{tabular}

${ }^{\#} 1$ : active wakefulness, $2:$ standing/sittingwith eyes open, $3:$ standing motionless with eyes closed, and 4 : sitting motionless with head drooped (sleeping posture).

\section{Results and Discussion}

A.s shown in Table 1, GLP-1 (7-36) induced sleeping posture (posture of the score 4) at 30 min following i.c.v. injection in a dose-dependent fashion when compared with the saline control. It produced the entire prevention of posture of the score 1 (active behavior). The present result was in agreement with other report for feeding behavior of the neonatal chick by Furuse et al. (1997 c), who implied that GLP-1 may cause sedation or narcolepsy (sleep-like behavior).

In young adult hens, during the sleeping posture (head tucked under a wing) and the resting posture with eyes closed, there is nearly always electrophysiological sleep which points towards a good correlation (vAN LuIJTELAAR et al., 1987). Thus, postures of the score 3 and 4 (GLP-1 induced sleep-like behavior) in the present result appear to be consider sleeping behavior on electrophysiology and GLP-1 is thought to have induce sleeping behavior in the neonatal chick. From the standpoint of the relationship between sleep-like behavior and feeding behavior, DENBOw et al. (1981) observed that i. c.v. injection of norepinephrine (NE) failed to stimulated food intake in the domestic fowl, presumably because it induced a narcoleptic response. Thus, there is the possibility that the anorexigenic effect of GLP-1 was due to GLP-1 induced sleep-like behavior by polyrrhea of NE. Indeed, central injection of fusaric acid (an inhibitor of dopamine- $\beta$-hydroxylase, a late-limiting enzyme in NE synthesis : RACz et al., 1985) which suppressed REM sleep in cats (SATOH and TANAKA, 1973), attenuates the effect of GLP-1 on food intake (BUnGo et al., unpublished data).

In conclusion, it is suggested that central administration of GLP-1 (7-36) amide may stimulate sleeping behavior in the neonatal chick.

\section{Acknowledgement}

This study was supported by a grant-in-aid for scientific research from the Ministry of Education, Science and Culture, Japan.

\section{References}

Davis, J.L., MASUoKa, D.T., Gerbrandt, J.F. and Cherkin, A. (1979) Autoradiographic distribution of L-proline in chicks after intracerebral injection. Physiology \& Behavior, 22 : 693-695. 
Denbow, D.M., Cherry, J.A., Siegel, P.B. and Van Krey, H.P. (1981) Eating, drinking and temperature response of chicks to brain catecholamine injection. Physiology \& Behavior, $27: 265-269$.

Furuse, M., Matsumoto, M., Okumura, J., Sugahara, K. and Hasegawa, S. (1997 a) Intracerebroventricular injection of mammalian and chicken glucagon-like peptide- 1 inhibits food intake of the neonatal chick. Brain Research, 755 : 167-169.

Furuse, M., Matsumoto, M., Mori, R., Sugahara, K., Kano, K. and Hasegawa, S. (1997 b) Influence of fasting and neuropeptide $\mathrm{Y}$ on the suppressive food intake induced by intracerebroventricular injection of glucagon-like peptide- 1 in the neonatal chick. Brain Research, $764: 289-292$.

Furuse, M., Matsumoto, M., Saito, N., Sugahara, K. and Hasegawa, S. $(1997 \mathrm{c})$ The central corticotropin-releasing factor and glucagon-like peptide-1 in food intake of the neonatal chick. European Journal of Pharmacology, 339 : 211-213.

LaRsen, P.J., T ANG-Christensen, M. and Jessop, D.S. (1997) Central Administration of glucagon-like peptide- 1 activates hypothalamic neuroendocrine neurons in the rat. Endocrinology, 138 : 4445-4455.

Navarro, M., De Fonseca, F.R., Alvarez, E., Chowen, J.A., Zueco, J.A., Gomez, R., Eng, J. and BLÄZQUEZ, E. (1996) Colocalization of glucagon-like peptide-1 (GLP-1) receptors, glucose transporter GLUT-2, and glucokinase mRNAs in rat hypothalamic cells : evidence for a role of GLP-1 receptor agonists as an inhibitory signal for food and water. Journal of Neurochemistry, $67:$ 1982-1991.

RACZ, K., KUCHEL, O. and BUU, N.T. (1985) In vivo release of adrenal catecholamine in rats by fusaric acid. European Journal of Pharmacology, 109 : 1-7.

SAтон, T. and TANaKa, R. (1973) Selective suppression of rapid eye movement sleep (REM) by fusaric acid, an inhibitor of dopamine- $\beta$-oxidase. Experientia, 29 : 177-178.

Snedecor, G.W. and Cochran, W.G. (1967) Statistical Methods, 6th ed. The Iowa State University Press, Iowa, USA.

Tang-Christensen, M., Larsen, P.J., Göke, R., Fink-Jensen, A., Jessop, D.S., Møller, M. and Sheikh, S. P. (1996) Central administration of GLP-1-(7-36) amide inhibits food and water intake in rats. American Journal of Physiology, 271 : R 848-R856.

Turton, M.D., O’Shea, D., Gunn, I., Beak, S.A., Edwards, C.M.B., Meeran, K., Chol, S.J., TAyler, G.M., Heath, M.M., Lambert, P.D., Wilding, J.P.H., Smith, D.M., Ghatei, M.A., Herbert, J. and Bloom, S.R. (1996) A role for glucagon-like peptide-1 in the central regulation of feeding. Nature, $\mathbf{3 7 9}$ : 69-72.

van LuiJtelaar, E.L.J.M., Van Der Grinten, C.P.M., Blokhuis, H.J. and Coenen, A.M.L. (1987) Sleep in the domestic hen (Gallus domesticus). Physiology \& Behavior, $41: 409-414$.

Wang, T., Edwards, G.L. and BAILE, C.A. (1996) Glucagon-like peptide-1 (7-36) amide (GLP-1) activates the hypothalamic-pituitary-adrenal (HPA) axis of rats. Society for Neuroscience Abstract, $22: 456$. 


\section{グルカゴン様ペプチド-1 の脳室内投与は新生ニワトリヒナの睡眠様 行動を引き起こす

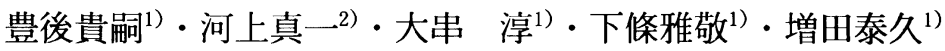 \\ 斎藤 昇 $^{3)} \cdot$ 長谷川信 $^{4)}$ ・菅原邦生 ${ }^{5)} \cdot$ 古瀬充宏 ${ }^{1)}$ \\ 1) 九州大学大学院生物資源環境科学科農学部, 福岡市 812-8581 \\ 2) 農水省九州農業試験場, 熊本県 861-1192 \\ 3) 名古屋大学大学院生命農学研究科, 名古屋市 464-8601 \\ 4) 神戸大学大学院自然科学研究科, 神戸市 657-8501 \\ 5) 宇都宮大学農学部, 宇都宮市 321-8505
}

\footnotetext{
グルカゴン様ペプチド-1（GLP-1）の中枢投与により ラットとヒナの摂食量が減少することが報告されている が, ヒナにおける GLP-1 の摂食抑制機構は今だ明らか になっていない。本研究は, GLP-1 が新生ニワトリヒナ の睡眠様行動を誘発するかどうかを明かにするために 行った。脳室内に投与した 0.03 および $0.1 \mu \mathrm{g}$ の GLP-1 （7-36）アミドは対照の生理的食塩水に比べてヒナの睡
}

眠様行動を引き起こすことが認められた。中枢神経系に おける GLP-1 は, ニワトリヒナの睡眠を誘発する因子 の 1 つであること可能性が示唆された。

(家离学会誌, $36: 377-381,1999$ ) キーワード : グルカゴン様ペプチド-1 (GLP-1), 睡眠様 行動, 脳室投与, 新生ニワトリヒナ 